\title{
Israel's Trade Alliances Strategy: Enjoying the Best of All Worlds
}

\author{
Nellie Munin ${ }^{1}$ \\ ${ }^{1}$ The law school, Zefat Academic College, Israel. \\ Correspondence: 11 Jerusalem st., Zefat 1320611 \\ Received: November 2, 2021 \\ Accepted: November 16, 2021 \\ Online Published: November 25, 2021 \\ doi:10.11114/ijlpa.v4i2.5409 \\ URL: https://doi.org/10.11114/ijlpa.v4i2.5409
}

\begin{abstract}
This article revisits Israel's trade and political alliance with the European Union - its major trade partner. The article examines the position calling to water down Israel-EU trade relations, considering EU's insistence on linking economic benefits with political advancement in the region, insights gained by the COVID-19 pandemic and substantial recent regional developments: Israel's trade diversification policy, the conclusion of Abraham Accords and the discovery of gas in the Eastern Mediterranean basin. Concluding that such a strategy may not serve the parties' interests best, the article explores ways to leverage these developments to further enhance EU-Israel partnership.
\end{abstract}

Keywords: EU, Israel, integration, COVID-19, Abraham Accords.

\section{Introduction}

Israel is a small country, situated in an unfriendly neighborhood. Its trade and economic development, as well as its security and food security, highly depend on its trade alliances. Israeli industries can exhaust their comparative advantage and economies of scale only by selling their products or services abroad. The constant risk of sudden isolation, due to regional political hostilities or any other reason, such as the recent COVID-19 pandemic, urges Israel to prepare alternative import sources on which it may rely to ensure security and food security supplies in times of crisis.

Consequently, for Israel, becoming part of a larger and stronger player such as the EU may be a very tempting idea, both economically and politically. The notion of enhancing Israel's integration with the EU, its major trade partner - either fully, by joining it as a member state or partly, beyond the current level of mutual cooperation - was thus occasionally toyed with ((Pardo and Peters, 2012, 2014; Pardo, 2013) in academic and political forums, particularly in Israel, gaining enhanced public and political attention in times of crises.

In terms of geographical proximity, Israel is only $300 \mathrm{KM}$ away from Cyprus, an EU member state. Apart for its importance in ensuring quick supply to Israel in cases of political or natural emergencies, this proximity is decisive to save expensive shipment and travel costs to remote destinations, and enable trade in perishable goods that could barely last long shipments, such as fresh foods, flowers, livestock, and fragile goods.

Israel and Europe share great cultural proximity. Many Israeli citizens are of European origins. More than half of the Israeli citizens are potentially entitled to an EU passport (Harpaz, 2013, 166-8) and more than 1 million carry one. Many Israelis speak European languages. The fact that EU is Israel's major trade partner reflects the high volume of mutual collaboration in business, industry and trade, proximity of consumer tastes and preferences and a high degree of Israeli reliance on the EU market.

The EU and Israel share commitment to democracy and the rule of law (Art. 1 Association agreement), as well as additional, universal values. ${ }^{\mathrm{i}}$

Nevertheless, the EU persistently refuses to consider Israel's membership, relying on the formal excuse that Israel is not 'a European state', as required in art. 49 of the Treaty on the European Union (TEU). ii Although the EU could have profited from having a member state situated in the Mediterranean region, the EU seems to be concerned with the effect such a move may have on its relations with other countries in that region, and maybe with the implications such an exception to the rule may have in terms of other requests for membership. For the EU, the small Israeli market as a whole may not be interesting enough for pure economic reasons, to justify Israel's full membership. The EU is interested in leveraging its economic importance for Israel to strengthen its political effect in the region, ${ }^{\text {iii }}$ establishing in it its 'normative power' status (Sher, 2018, 121; Munin and Sitbon, 2021). The Association agreement it shares with Israel seems to suffice to meet these goals. Thus, the EU includes Israel in the Mediterranean group of countries, subject to 
cooperation frameworks with the EU such as the Barcelona Process, the ENP and the UFM ${ }^{\mathrm{iv}}$. However, the EU does not hurry to exhaust the potential of these frameworks. In 2004 a mutual team of experts worked out a detailed action plan ${ }^{v}$ to turn some potential EU-Israel Association Agreement provisions effective. Despite the long time that passed, this action plan has not been fully realized, since the EU subjects such advancement to political advancement toward solution of the Israeli-Palestinian conflict. (Nathanson and Stteter, 2006). For the same reasons, almost 27 years after its conclusion, the EU refrains updating the association agreement. The association council - the highest political instance of the EU-Israel Association Agreement - has not been convened since 2012 (European Parliament, 2020), although according to article 67 of the agreement it should have convened at least once a year. This approach invokes Israeli frustration, perceived as imposing unnecessary limits to the potential development of mutual economic cooperation.

Joining the EU could have exposed Israel to even more substantial EU political pressure to solve the Israeli-Palestinian conflict in the candidacy phase. However, judging upon the Cypriot-Greek experience, ${ }^{\mathrm{vi}}$ had Israel survived this phase, after becoming a full member it could automatically enjoy the entire market liberalization 'package' the EU offers to its members, while EU's economic-political leverage over it might have been substantially eroded.

In light of the reasons for this conflict, embedded in deep territorial and religious questions, it is hard to believe that becoming an EU member would have substantially changed Israel's status in the eyes of its neighbors, although they might have been strategically deterred. In their eyes, accepting Israel as a member without making it change its position towards the regional conflict would have been interpreted as one-sided EU support in Israel, which is clearly not in EU's interest and does not reflect its position. An idea of tempting Israel and the Palestinians to engage in a peace agreement with the 'carrot' of becoming EU members in return was invoked in the past (e.g. Burston, 2017). However, the EU never suggested it. Recent interventions of external players such as Iran in the Israeli-Palestinian conflict seem to further complicate the scene and diminish the chances for a quick solution.

In this reality, Israel's independence allows it to seek political support from other strong, global players such as the US (its major political ally and second trade partner) and even, to a certain extent Russia, perceived in Israeli eyes as fairer mediators than the EU.

EU's approach is one major reason why, in recent decades, Israel decided to start diversifying its trade alliances, beyond Europe and America, turning its attention mainly to Asia (Levkowitz, 2017). It recently concluded a free trade area agreement (FTAA) with South Korea and is now on the verge of concluding an FTAA with India (Arkin, 2021), negotiating also with Vietnam, China and the Euro-Asian Economic Union (EAEU, including Russia, Kazakhstan, Belarus and Armenia). The conclusion of Abraham Accords in 2020, between Israel, the United Arab Emirates (UAE), Morocco, Bahrein and Sudan, opened new trade horizons for Israel and changed the political 'peace for land' formula that stagnated the Israeli-Arab conflict for many years. In this front, Israel is on the verge of concluding an FTAA with UAE (Gorodinski, 2021). The COVID-19 pandemic seems to have reinforced this approach, illustrating the importance of trade partners' diversification (Munin, 2020).

The discovery of gas in the Eastern Mediterranean basin led to the initiation of regional collaboration with Egypt, Jordan, Greece and Cyprus, aimed at exporting part of this gas to Europe.

Allegedly, these developments strengthen Israel's global political and economic status, thus potentially weakening the EU's economic leverage over it. While some believe that Israel should take advantage of this new equilibrium to decrease EU's importance to its economy, this article contends that this result may mature in the long term. Currently, EU's share in Israel's external trade does not seem to decrease and some of its advantages specified above are irreplicable. Thus, in the meantime Israel may profit from enhancing a positive trade agenda with the EU, to the extent that the EU would be willing to collaborate with it.

\section{Major Fields of Current Economic Cooperation Between Israel and the EU}

Despite their ongoing political controversy, the EU and Israel cooperate in many economic aspects. This section describes some major fields of this collaboration, illustrating EU's inevitability to the Israeli market.

\subsection{Trade}

The EU is Israel's major trade partner: in 2020 mutual trade flows between Israel and the EU exceeded 41.8 bn $\$$, almost one third of Israel's total international trade. Their trade balance reflects the asymmetry of their relations and size, as the scale of Israeli imports from the EU (27.1 bn\$) is considerably higher than the scale of its exports to the EU (14.6 bn \$) (Israeli Central Bureau of statistics, 2021). Their Association Agreement facilitates trade in goods by dismantling most trade barriers, such as customs duties, quotas, discriminating internal taxation and measures having equivalent effect.

The system of pan Euro-Mediterranean cumulation of origin, ${ }^{\mathrm{vii}}$ launched by the EU in 2013, did not enhance cooperation between Israel and its Arab neighbors as expected (Tovias, 2021), yet it encourages collaboration between Israeli industries and counterparts from Turkey, EFTA states, the UK, and Ukraine, exhausting their respective comparative 
advantages, in the production of goods entitled to benefits when exported to the EU. EU customers profit from this arrangement a greater variety of products in reduced prices.

\subsection{Agriculture}

EU-Israel's trade in agricultural products is subject to a sectoral agreement from 2010, which works well (Tovias, 2021). The geographical proximity between Israel and the EU enhances trade in agri-food between them. Israel is mentioned among top EU agri-food trade partners, both as an origin and as a destination. (European Commission, 2020). In the height of the COVID-19 pandemic, Israel intensified imports of agricultural goods from the EU, to ensure food security, e.g. eggs.

\subsection{Aviation}

An EU-Israel 'Open Skies' agreement (European Commission, 2020a) was concluded in 2013, following an EU initiative from 2006. The $E U$ wanted to replace old bilateral agreements of its individual members with a modern comprehensive agreement, to make it easier for its carriers to supply aviation services to Israel. This agreement considerably opened the Israeli aviation and tourism markets to competition, substantially lowering flight prices and extending market's scope. It enhances tourism between the parties (European Commission, 2019a). Currently, the parties negotiate so called 'OneStop Security Arrangements' to reach full EU recognition of Ben Gurion airport security arrangements. (Tovias, 2021).

In terms of space cooperation, Israel is one of a few non-EU countries that joined EU's Galileo navigation project (European GSA, 2020) since its beginning, substantially contributing to it in terms of technological know-how.

\subsection{Environment}

The geographical proximity between the parties underlines mutual environmental interests. For example, between 201517 the EU launched a twinning project with the Israeli Ministry of Environmental Protection, aiming to modernize and effectively implement Israeli environmental regulatory and management framework. (MoEP, 2020).

\subsection{Health}

Many Israelis study medicine in the EU, due to a shortage of Israeli medical schools to meet this demand. Israel saves the money necessary to educate future physicians while EU medical schools profit this money. Israel participates in EU initiatives such as the European Innovative Partnership on Active and Healthy Ageing (EU Commission, 2020b).

The COVID-19 pandemic illustrated other ways of medical collaboration. Most of the vaccines used in Israel originated in European countries, due to geographic proximity. Moreover, Israel asked the EU (and the US, two main destinations for Israeli travelers) to coordinate with it the rules for travelers, under which eligible people who have not received coronavirus booster shots will no longer be recognized as vaccinated. (The Times of Israel, 2021). Recently, Israel and the EU reached a reciprocal COVID passport agreement, facilitating mutual travels between them. (Globes, 2021). These developments reflect mutual trust of EU's and Israel's health regulators, that could facilitate future mutual recognition practices in other medical fields.

\subsection{Research, Development and Education}

Israel is a globally leading power in terms of R\&D. Nevertheless, Israeli players in these fields suffer constant shortage of financing, due to the limited resources Israel can dedicate to these purposes. This need meets $E U$ 's constant striving to develop and support R\&D, known as a substantial growth engine, including by encouraging collaboration with nonmembers. Israel is the only non-European country which participated in Horizon 2020 (European Commission, 2020c) in projects involving, among other fields, nanotechnology, health, environment and communications. Due to the high EU interest in such collaboration, it has never been subject to political fluctuations, to the mutual benefit of both parties. Hence, Israel will participate in the new program, Horizon Europe. (Keidar, 2021).

Israel is inspired by EU initiatives with regard to higher education. Enhanced collaboration in this field between Israeli higher education institutions and EU counterparts is highly encouraged and facilitated by the Israeli Council for Higher Education under the auspice of Erasmus+ (European Commission, 2020d) and Bologna Process (European Commission, 2020 e) programs. By 2020, the EU had financed more than 7,000 Israeli students' stays in European universities. In 2018, more Israeli students studied in the EU than in the US (Tovias, 2021).

This process raises the academic level of all its participants, by creating synergy of academic resources, cultures and perceptions (Terry, 2008), ensuring high quality communication and collaboration between them. (Stone and Patrick, 2013).

For the $E U$, adherence of non-EU members such as Israel to these educational programs is an indication for exercising its 'normative power'. (Zehavi, 2018). 
The R\&D and education platforms described above indirectly encourage trade between the parties, by raising awareness to services and products of the other party, by facilitating mutual market exposure and by creating networking between producers and suppliers (e.g., ISERD, 2019).

\section{Aspects for Future Enhanced EU-Israeli Market Integration}

The success of current EU-Israel collaboration motivates Israeli desires for its expansion, which could theoretically be obtained by full EU membership, and alternatively by enhanced liberalization.

\subsection{The Legal Aspect}

Becoming an EU member state would have required Israel to adopt the Acquis Communautaire, the full body of EU law, and fully subordinate its legal regime to EU legislation and courts. Such a step could have facilitated EU's imposition of its agenda on Israel, using substantial legal and economic instruments embodied in its law. Israel's membership would have enlarged EU's population and territory, giving it a territorial anchor in the Mediterranean region, and consequently broadening the scope of its legal effect as a 'normative power'.

In the long run, such a European anchor in the middle east could have served to enhance the realization of the Barcelona vision, of turning the Mediterranean region into a free trade area, following the EU model.

For Israel, this would have born several implications:

\subsubsection{The substantive aspect}

Current EU law is a product of more than sixty years of negotiations, drafting and legal interpretation in which Israel did not participate. Israel did not have a chance to influence its contents and it does not necessarily serve Israeli interests in the best way.

As an EU member, Israel would have had the right to fully participate in any EU legislation process, trying to enhance its interests. Nevertheless, being a relatively small country compared to other EU players, its influence over these processes would have been limited. Consequently, Israel could often find itself obliged to obey rules which are not serving best its interests.

Parts of this huge body of law may be more progressive than current Israeli respective law, thus potentially improve the Israeli legal system upon its adoption. This fact is recognized by the Israeli legislature and courts, already referring to it as a comparative source of ideas and inspiration (Pardo and Zemer, 2019). ${ }^{\text {vii }}$

However, while independent, Israeli decision makers may opt for alternative solutions offered by other national systems, or by international standards, or develop original arrangements that suit domestic needs best.

For example, in the beginning of the Millennium Israel considered whether to adopt EU standards regarding obligatory securities issuance documents. A dialogue with the Israeli business community revealed that adopting EU standards may be burdensome for Israeli companies desiring to issue securities in the NASDAQ and in other non-EU security markets. Consequently, Israel abandoned this initiative. However, Twinning (liaise of EU experts with Israeli public sector for 1824 months) and TAIEX (bilateral meetings between EU and Israeli officials) activities, introduced under the ENP, to which the EU allocates 2 million Euro per year, lead a discrete process of approximation of Israeli regulation in the domains of education, communication, and environment, with a future prospect to cover welfare as well. (Tovias, 2021).

\subsubsection{The institutional aspect}

Becoming an EU member would subordinate Israel to the superiority of EU courts, considered the highest instances interpreting EU law. This would derogate the current independent powers of the Israeli court system.

The cases of Brita (CJEU, 2010) and Psagot (CJEU, 2019), where the CJEU excluded the territories captured by Israel during regional wars from the scope of EU-Israel's Association Agreement, clearly reflect the gap of political insights between Israel and the EU (see, e.g. Munin, 2015, 2015a; Munin and Sitbon, 2021). In Israeli eyes, these CJEU decisions effectively undermine collaboration leading to normalization between Israelis and Palestinians in these territories, excluding their products from Agreement's benefits. ${ }^{\text {ix }}$

The Israeli High Court of Justice opts for an alternative, pragmatic approach which recognizes the limits of public international law to regulate daily lives in areas suffering more than fifty years of contested sovereignty, striving to ensure reasonable life conditions for all citizens in such areas. (See, e.g., Israeli Court of Justice, 1981, 1982). ${ }^{\mathrm{x}}$

It is highly probable that had Israel joined the EU, the CJEU would have challenged such Israeli High Court of Justice decisions, replacing them with the Brita/Psagot approach. ${ }^{\mathrm{xi}}$

\subsection{Enhancing Economic and Trade Collaboration}


EU membership is not currently feasible for Israel, and in certain aspects its current independent position is preferable for it. Yet, for the reasons specified and despite recent prospects for trade diversification, it is clear to both parties that currently, Israel's trade relations with other countries do not suggest a satisfactory alternative to its trade relations with the EU (Eran, Pinfold and Roset, 2018, 139-144). This section examines the pros and cons of enhancing their trade liberalization in different fields.

\subsubsection{Trade}

The EU is a customs union. As such, its external trade policy and law is fully integrated.

As a small, export-oriented market, Israel is trying to maximize global trade opportunities. While it could profit from joining a great global trade block like the EU, enjoying its considerable global negotiating power, Israel's isolation in the region and unique security challenges dictate a need for maximal flexibility in terms of external trade policy. Its independence from EU's common trade policy allows it to opt for trade rules and engage in international trade agreements best serving such goals.

COVID-19 illustrates the importance of this independence: Israel's early engagement in agreements with Pfizer and AstraZeneca enabled quick vaccination of the Israeli population and consequently, the quick return of almost full market operation, ensuring quick recovery of its economy from the crisis. This would not have been possible had Israel been an EU member, subject to EU discipline on this issue.

The fact that Israel is not bound by the common EU trade policy also facilitates its trade diversification policy.

Due to EU's refusal on political and other grounds, ${ }^{\text {xii }}$ Israel-EU Association Agreement does not yet provide for a free trade area in services (art. 29 Association Agreement), amounting for more than 70\% of both parties' GDP. The implications of this misfortunate fact are somewhat watered down by current transportation and technological developments, facilitating trade and e-trade of services, by EU passports certain Israeli service providers hold and by the option Israeli suppliers have to establish and act through European Companies (SE) (European Commission, 2020f).

\subsubsection{Financial and Monetary Aspect}

The EU strives for full internal financial integration (Juncker, 2015, 2017).

Joining the EU would have subjected Israel to its financial and monetary integration process. For the $E U$ this result could have been desirable: Israel is a relatively economically and financially strong and stable country, which could strengthen EU's financial alliance.

For Israel, such a step might have involved advantages and disadvantages:

\subsubsection{Financial Commitment}

While Israel is considered a developed country with GDP per capita of 43,610 \$ for 2020 (World Bank, 2021), more than $15 \%$ of its GDP is spent on its direct and indirect security needs (Zeira, 2018, 129).

Had Israel become an EU member, it should have paid its share to the EU budget, based on its gross national income (GNI) ${ }^{\text {xiii }}$ without taking into account these unique constraints. Being a relatively economically stable and prosperous country, it would have been reasonably expected to be a contributing member. This obligation could have imposed another considerable burden on its budget. At the same time, Israel could have enjoyed EU financing and full participation in all EU programs, wholly or partly offsetting this burden. It is thus difficult to assess what would have been its net contribution.

Under the current arrangement, Israel and the EU decide the fields of mutual collaboration. Due to its non-membership, the $E U$ has full discretion whether to allow Israel's access to EU programs, and it exercises it subject to its political and economic interests. For example, nine Israeli organizations won Horizon 2020 Innovative Program grants to tackle COVID-19 (NoCamels, 2020).

Israel constantly risks EU refusal regarding its participation in specific programs. However, Israel pays membership fees only for programs in which it participates, thus effectively sparing the need to cross-subsidize other, relatively weaker EU members.

\subsubsection{Financial Instabilities Spillover}

Avoiding or minimizing financial instabilities spillover is a major internal $E U$ goal. However, despite the substantial steps it took since the recent financial crisis, EU leaders admit that there is still a long way to go (Juncker, 2015, 2017).

In the beginning of the Millennium, when the Euro was introduced, some experts in Israel recommended considering unilateral replacement of the New Israeli Shekel with the Euro as the Israeli currency. (E.g. Melnick, 2003). These experts thought that the Israeli economy may indirectly profit from the potential growth of the EU market, reflected by a growing strength of the Euro. Opponents pointed on the disadvantages: unilaterally subordinating the Israeli economy to the 
fluctuations of a currency regarding which Israel had no say, being a non-member of the European Monetary Union (Munin, 2003, 40) and the potential effect of such a step on Israel's connections with other economies, such as the US (Tovias, 2003, 6).

Had Israel joined the EU/European Monetary Union (EMU), it could have participated in the monetary decision-making process, although its effect would have been considerably small.

The fact that Israel did not engage in high levels of market integration with other countries, helped it avoid the quick spillover of the global financial crisis that severely hit the EU since 2010. Unlike EMU members, Israel maintained independent powers to determine the national market's interest rate and the authority to devaluate their currency, when necessary to prevent the financial crisis' adverse effects.

The financial crisis encouraged strict EU regulation, among other things forcing EU member states to submit their national draft budgets to review by EU institutions, before voting on them in the national parliaments (European Union, 2011, 2011a, 2011b) and subjecting national monetary systems to strict EU regulation and surveillance. (E.g., Munin, 2016).

Being a non-EU member, Israel is free of these obligations, enjoying total independence in drafting its budget and performing financial market surveillance according to its national needs. At the same time, adherence to such EU constraints could have spared Israel unnecessary expenses or biases emanating from domestic political pressures. Maybe it could have prevented a reality in which between 2018 and 2021, due to domestic political fragmentation, the Israeli government was unable to decide a state budget (bearing sever market implications, particularly in the COVID-19 era).

\subsubsection{Financial Solidarity}

During the financial crisis of 2010, EU mechanisms and strong EU member states financially helped vulnerable EMU member states, directly and indirectly. As a non-EMU/EU member, Israel did not have to share this financial burden. Simultaneously, had Israel been adversely affected by the crisis, it would not have been entitled to the financial assistance EMU/EU member states received from these resources.

While Israel managed to skip severe consequences of that financial crisis, its economy was substantially hit by the COVID-19 crisis. In August 2020 the Israeli Bureau of Statistics estimated a yearly decrease of $28.7 \%$ in Israel's GDP the greatest decrease since Israel's establishment (Caspin, 2020). Had Israel been an EU member state, it could have profited from generous EU financial and economic programs aimed at helping EU members to pull out of the COVID-19 crisis (Castellarin, 2020; Munin and Malka-Tiv, 2021). In such circumstances, Israeli independence may have proved a disadvantage, depending on the ratio between expected members' contribution and the offered assistance. Recently the Israeli market shows quick signs of recovering from the crisis, which may be broadly attributed to Israel's economic independence and full flexibility to take all necessary measures to achieve this goal. However, OECD's Economic Survey of Israel (2020) recommends a long list of structural improvements which may strengthen the Israeli economy against future crises. These include, among other things, upgrading infrastructure, improving educational outcomes, strengthening the fiscal framework for local governments, supporting the poor, simplifying tax systems and reducing economic distortions, improving environmental outcomes and reducing health risks. Many of these issues are neglected due to internal political pressures, or financial shortage. EU membership could have helped to realize them.

The EU may extend its financial assistance to support the Mediterranean region even in the current layout. A recent EuroMeSCO survey marks climate change and inclusive regional growth among the top challenges mentioned by Mediterranean (including Israeli) experts as fields where EU contribution may have an added value. (Tovias, 2021).

\subsection{Fighting Centralization}

The $E U$ is a huge market, with strong competition rules and enforcement mechanisms.

Israel is a small and very centralized economy (Ben Yosef, 2008; Zeira, 2018, 355-396). For example, the Israeli financial services sector suffers lack of competition that adversely affects prices. The Israeli banking sector is dominated by five major players that pragmatically act as a monopoly. Israel has one stock exchange, in Tel Aviv, mainly dominated by institutional players. Consequently, many Israelis, particularly individuals, prefer to invest in foreign, more competitive stock exchanges. In recent years the Israeli regulator took several steps to enhance competition in the insurance sector. Nevertheless, these sectors are still highly centralized and non-competitive (Stein, 2015).

Extending trade liberalization between Israel and the EU to include financial services (art. 48 Association agreement) could have substantially improved competitiveness of this market, particularly had Israel approximated its relevant laws to EU regulation (European Commission, 2019b). It could facilitate the access of Israeli consumers to EU suppliers, and of EU suppliers to the Israeli market, forcing Israeli service providers to become more competitive. ${ }^{\text {xiv }}$ While such a step could have had a crucial effect for the Israeli market, its effect on EU suppliers would have been marginal, due to the 
small size of the Israeli market. Thus, for the $E U$, this is not a priority. It prefers to channel its efforts towards huge financial markets like the US, Russia and strong Asian players first.

Israel could have obtained a similar effect by including in its other trade agreements provisions for mutual liberalization of their parties' financial markets. However, for the time being such provisions are included only in Israel-Panama free trade area agreement of 2018. (Israeli Ministry of Economy, 2020, annex 9-C).

\subsection{Free Movement of Persons}

Free movement of persons is one of the four freedoms underlining the $E U$, mandatory for all its member states.

Israel was established following the atrocities of World War II, with the clear aim of creating a national home for the Jewish people. This aim is well enshrined in its declaration of independence, perceived by the Israeli Court of Justice as a constitutional document.

Current Israeli population exceeds 9.3 million citizens, of which about $74 \%$ are Jews and $21 \%$ are Arabs. (Israeli bureau of statistics, 2021). Israel is constantly struggling to keep the Jewish majority, realizing that otherwise it may lose its unique Jewish character which is its major 'raison d'etre'.

Had Israel become EU member, many Israeli citizens desiring to work, learn or live in EU member states could have enjoyed the freedom of movement. At the same time, Israel would have been forced to open its borders to EU citizens desiring to live in it. Israel's experience with labor immigrants and the EU experience with the application of this freedom reflect that even when applied with all due precaution, it may cause a detrimental change in the texture of domestic communities (e.g., France). In the Israeli context, it may highly augment the risk of losing the Jewish majority and character. This fear, which was always on the table, is reinforced by recent years' huge waves of Muslim immigration to the EU.

It is added to constant security concerns ${ }^{\mathrm{xV}}$ and concerns with regard to abuse by antisemitic players (FRA, 2020).

In Israeli Jewish eyes, this seems to be a decisive consideration against joining the EU, particularly as a considerable number of the Israeli nationals hold, or are entitled to hold, an EU passport, thus already entitled to free movement in the EU.

The Israeli Arab population, which does not exhaust its full working and business potential (Zeira, 2018, 332-336), may favor such a step, for opening new individual opportunities for jobs, business, education etc. in EU member states and for its potential social and cultural effect on Israel.

\subsubsection{Free Movement of Persons and Trade in Services}

The fact that this freedom does not apply between EU and Israel considerably undermines the free movement of services between them.

Except where security considerations are involved, Israel and the EU share the common global approach ((E.g. Kakabadse, 1987), more tolerant to short or medium term stays, facilitating tourism, professional collaboration etc., than to long term or permanent stays of foreign citizens. To a certain extent, this approach allows Israel to balance the interest of keeping its Jewish nature, with the interest of benefitting from foreign expertise in different fields, and from intensive tourism (art. 54 Association Agreement). ${ }^{\mathrm{xvi}}$

In the short run, both parties could have profited from some fine-tuning, mutually recognizing these rights in cases serving both parties' interests, by establishing a legal framework to determine their terms. ${ }^{\text {xvii }}$ For example, in the height of COVID-19 crisis, Israel suffered a shortage of medical services suppliers, that could have been recovered by such arrangements.

For the time being, Israel has made a first attempt to liberalize the movement of service suppliers, to a limited extent, only in its trade agreement with Panama from 2018, probably assuming that the relatively low level of market integration between them and the geographic distance would prevent a broad scale of accesses to Israel of service suppliers from Panama.

\subsection{Regional Collaboration and Development}

Regional initiatives for the Mediterranean (envisioned by art. 44 Association Agreement) were greatly undermined in recent years due to the political escalation in the region, enhanced by what is known as the 'Arab Spring'. (FEPS and MACRO, 2016). Israel found it harder than in relatively stable times, to collaborate with its neighbors. Even Jordan and Egypt, sharing peace agreements with Israel, preferred to collaborate only behind the scene, to avoid hostile opposition.

This ongoing reality substantially limited the fulfillment potential of EU initiatives for regional collaboration, e.g. under the UFM framework. To the extent these programs exist, they help to preserve and somewhat improve the limited dialogue between regional players. 
In recent years Israel took advantage of loans granted by the European Investment Bank (EIB) under their framework agreement of 2006, to establish unilateral projects bearing regional implications. For example, the EIB is co-funding the establishment of a water desalination device in Ashdod (a city constantly attacked from Gaza Strip in the south-west of Israel) (Teleniri, 2009). This is one out of several such devices Israel developed and operates, having a substantive potential for solving the regional chronic lack of drinking water. ${ }^{\text {xiii }}$ The increase in available drinking water enabled the conclusion of a recent agreement between Israel and Jordan, in which Israel committed to double the annual water supply to Jordan, to enhance good neighborhood (Eichner, 2021). The EIB also co-finances the first thermo-solar power house in Ashalim, in the Negev (Gutman, 2014). This is a project with regional environmental implications, which the Bedouin population in that area may share. The EIB financed part of the developing infrastructure of the EastMed gas pipeline (collaboration with Cyprus and Greece to build infrastructure transferring Israeli gas to the EU) (Euronews, 2020).

The EIB also offers loans to private investors in the region. Some of them were offered through Horizon 2020, encouraging new technologies. Israeli companies enjoying such financing include Brenmiller Energy, for an advanced green energy storage facility in Dimona, in the south of Israel. (Globes, 2019), and Biondvax, developing a universal vaccine for flue. (Israeli Ministry of Economy and Industry, 2017). In 2020, the EIB Signed a collaboration agreement with the Israel Innovation Authority and a 50 million Euro financing agreement with Pluristem to develop therapies for COVID-19 and other unmet medical needs. (European Commission, 2020g).

Financial support for regional projects is an indirect EU constructive facility affecting the Mediterranean region, which is more acceptable by all regional players than direct political interference.

SMEs, forming a substantial part of the Israeli economy, suffer constant financing difficulties on regular bases. They are particularly hit by the economic implications of COVID-19. They can profit from loans offered by the EIB.

Such loans can also make a difference for SMEs ran by women in conservative religious and traditional communities, who can exhaust their work potential and improve their economic situation by working from home, to satisfy cultural constraints. ${ }^{\text {xix }}$ (Munin, 2013).

Had Israel joined the EU, the scale of EU funding for such projects could have substantially augmented.

The recent Abraham Accords of September 2020, may create a new regional reality and atmosphere, encouraging other Arab countries to join regional collaboration (Munin, 2020a). The EU could enhance this process by suggesting financial and technical support, or rather lose some of its influence over the region, in light of these new players' involvement.

The gas discoveries in the Eastern Mediterranean basin may have created another way out of the regional deadlock. They encouraged collaboration between Israel, Egypt, Jordan, Cyprus and Greece, aiming at exporting gas to the EU through the ambitious EastMed Pipeline. This initiative is observed as a strategic window of opportunity for expanding cooperation with the EU, desiring to diversify its energy sources, but also with the region, as Egypt aspires to become a regional hub through which Israeli gas could be traded with other regional partners. The Regional Gas Forum, established in 2019, including Israel, Egypt, Cyprus, Greece, Italy, Jordan, the Palestinian Authority and France, with the EU and the US as observers, is a platform for further regional dialogue and collaboration (Mitchell, 2020). The Israeli and Egyptian triangular model of political, economic, energetic, cultural collaboration with Greece and Cyprus may serve as inspiration to other regional players such as Jordan and the Palestinian Authority. These new interests seem to outweigh the IsraeliPalestinian conflict. However, this collaboration is challenged by other regional players (Harari, 2021), such as Turkey (Soler, 2021), which need to be included in it to ensure its full success.

\section{Conclusion}

While full EU membership is not feasible for Israel at this stage, and does not seem to optimally serve both parties' interests, both the EU and Israel could profit from enhancing their relations, by full realization, upgrade and modernization of their Association Agreement.

EU's insistence to subject advancement of such economic integration to political results in the region seems to open the way for other, political and economic players. In the long run, the new Abraham Accords, expected to be followed by mutual trade and economic agreements, Israel's trade diversification policy and the regional gas initiatives could erode the economic importance of the EU to Israel and to the Mediterranean region. Global changes in the patterns of international trade, including the ongoing shift from trade in goods to trade in services, the development of e-commerce and of global supply and value chains (De Backer and Miroudot, 2014; Demertzis and Masllorens, 2020), may enhance this drift. For their best respective interests, both Israel and the EU should better choose to avoid these consequences by leveraging these regional developments to enhance their partnership. 


\section{References}

Abraham Accords (2020). https://www.state.gov/the-abraham-accords/

Arkin, Dan (2021). Israel and India towards concluding an FTA. IsraelDefence, 24.10 .21 [Hebrew] Retrieved from https://www.israeldefense.co.il/node/52288

Assenburg, M. (2019). Political paralysis: the impact of divisions among EU member states on the European Role in the Israeli-Palestinian conflict.In: Assenburg, M. and Goren, N. (eds.) Divided and divisive: Europeans, Israel and the Israeli-Palestinian peacemaking. Retrieved from https://www.swpberlin.org/publications/products/fachpublikationen/Asseburg_PAX_REPORT_Divided_Divisive.pdf

Ben Yosef, T. (2008). Welcome to the Free Market. Tel Aviv: Zivonim.

Burston, B. (2017). Opinion: Peace Plan for a New Era: Israel and Palestine Should Apply to Join the EU. Haaretz, 8.8.17. Retrieved from https://www.haaretz.com/opinion/.premium-peace-plan-for-new-era-israel-palestine-should-jointhe-eu-1.5441165

Caspin, T. (2020). Israel in the Greatest Recession Since its Establishment. Davar, 17.8.2020 [Hebrew]. Retrieved from https://www.davar1.co.il/242431/

Castellarin, E. (2020). The European Union's Financial Contribution to the Response to the COVID-19 Crisis: an Overview of Existing Mechanisms, Proposals Under Discussion and Open Issues. Retrieved from https://www.europeanpapers.eu/en/europeanforum/european-union-financial-contribution-response-to-covid-19

CJEU (2010). CJEU (2010). C-386/08 Brita GmbH v. Hauptzollamt Hamburg-Hafen 2010 ECJ EUR-Lex LEXIS 63 (25 February 2010).

CJEU (2019). Case C-363/18 Organization juive Europeenne, Vignoble Psagot LTD v. Ministre de l'Economie et des Finances. Retrieved from http://curia.europa.eu/juris/liste.jsf?num=C-363/1

De Backer, K. and Miroudot, S. (2014). Mapping Global Value Chains. ECB Working Paper No. 1677. Retrieved from https://www.ecb.europa.eu/pub/research/working-papers/html/index.en.html

Declaration of Principles on Interim Self-Government Arrangements. September 13, 1993, ('Oslo Agreement'). Retrieved from https://mfa.gov.il/mfa/foreignpolicy/peace/guide/pages/declaration\%20of\%20principles.aspx

Demertzis, M. and Masllorens, G. (2020), "The Cost of Coronavirus in Terms of Interrupted Global Value Chains", Bruegel Blog Post. Retrieved from https://www.bruegel.org/2020/03/the-cost-ofcoronavirus-in-terms-ofinterrupted-global-value-chains

Eichner, I. (2021). Agreement signed: annual water supply from Israel to Jordan will be doubled. Ynet 12.10.21 [Hebrew]. Retrieved from https://www.ynet.co.il/news/article/skepjtmbf

Embassy of Israel, Madrid. (2016). Savta Jamila Stars at Women who Transform the World in Segovia, Spain. Retrieved from https://mfa.gov.il/mfa/israelexperience/people/pages/savta-gamila-stars-at-women-who-transform-the-world14-mar-2016.aspx

Eran, O., Pinfold, R. G. and Roset, S. (2018). Issues in Israel-EU Economic relations. In: Rozner, Yotam and Kantor, Adi (eds.) The EU in Times of Upheavals: Trends, Challenges and Implications for Israel. Tel Aviv: INSS [Hebrew]. Retrieved from https://www.inss.org.il/he/wp-content/uploads/sites/2/2018/05/Memo175EU-1.pdf

Euro-Mediterranean Agreement establishing an association between the European Communities and their Member States, of the one part, and the state of Israel, of the other part, concluded in 21 June 2000, OJ L 147/3. Retrieved from http://www.eeas.europa.eu/archives/delegations/israel/documents/eu_israel/asso_agree_en.pdf

European Commission (2011). Commission Decision of 31 January 2011 pursuant to Directive 95/46/EC of the European Parliament and of the Council on the adequate protection of personal data by the State of Israel with regard to automated processing of personal data, 1 February 2011 (OJ L 27/39).

European Commission (2013). 2013/C205/05 Guidelines on the Eligibility of Israeli Entities in the territories Occupied 
by Israel since June 1967 for Grants, Prizes and Financial Instruments Funded by the EU from 2014 Onwards, 19 July 2013 (OJ C 205/5).

European Commission (2013a). Commission implementing regulation (EU) No. 594/2013 of 21 June 2013 amending implementing regulation (EU) No. 543/2011 as regards marketing standards in the fruit and vegetables sector and correcting that implementing regulation, 22 June 2013 (OJ L 170/43).

European Commission (2014). Commission Implementing Regulation (EU) no. 166/2014 of 17 February 2014 amending Regulation (EC) No 798/2008 as regards certification requirements for imports into the Union of meat of farmed ratites for human consumption and the entries for Israel and South Africa in the list of third countries or territories, 1 December 2005 (OJ 2014 L 54/2).

European Commission (2015). Interpretative Notice on indication of origin of goods from the territories occupied by Israel since June 1967. C (2015) 7834 final, 11 November 2015). Retrieved from http://eeas.europa.eu/delegations/israel/documents/news/20151111_interpretative_notice_indication_of_origin_of_ goods_en.pdf

European Commission (2017). Integrated Financial Reporting Package - Overview. Retrieved from http://ec.europa.eu/budget/library/biblio/media/2017/2017_IFRP_brochure_web_final.pdf

European Commission (2017a). White Paper on the Future of Europe. Retrieved from https://ec.europa.eu/commission/sites/beta-political/files/white_paper_on_the_future_of_europe_en.pdf

European Commission (2019). The pan-Euro-Mediterranean cumulation and the PEM Convention. Retrieved from https://ec.europa.eu/taxation_customs/business/calculation-customs-duties/rules-origin/general-aspectspreferential-origin/arrangements-list/paneuromediterranean-cumulation-pem-convention_en

European Commission (2019a). International Aviation: Israel. Retrieved from https://ec.europa.eu/transport/modes/air/international_aviation/country_index/israel_en

European Commission (2019b). EU Banking and Financial Services Law. Retrieved from https://ec.europa.eu/info/law/law-topic/eu-banking-and-financial-services-law_en

European Commission (2020). Agri-Food Trade Statistical Facts Sheet: European Union - Israel. Retrieved from https://ec.europa.eu/info/sites/info/files/food-farming-fisheries/farming/documents/agrifood-israel_en.pdf

European Commission (2020a). Agreement Between the European Community and the State of Israel on Certain Aspects of Air $\quad$ Services. Retrieved from https://ec.europa.eu/transport/modes/air/international_aviation/country_index/israel_en

European Commission (2020b). European Innovation Partnership on Active and Healthy Ageing. Retrieved from https://ec.europa.eu/eip/ageing/ec-world-countries/israel_en

European Commission (2020c). Horizon 2020. Retrieved from https://ec.europa.eu/programmes/horizon2020/en European Commission (2020d). ERASMUS+. Retrieved from https://ec.europa.eu/programmes/erasmus-plus/node_en European Commission (2020e). The Bologna Process and the European Higher Education Area. Retrieved from https://ec.europa.eu/education/policies/higher-education/bologna-process-and-european-higher-education-area_en

European Commission (2020f). Setting Up a European Company (SE). Retrieved from https://europa.eu/youreurope/business/running-business/developing-business/setting-up-europeancompany/index_en.htm

European Commission (2020g). EIB Signs Collaboration with Israel Innovation Authority and 50 Million EURO Financing Agreement with Pluristem to Develop Therapies for COVID-19 and Other Unmet Medical Needs. https://ec.europa.eu/commission/presscorner/detail/en/IP_20_783

European Court of Justice (2000). C-219/98 Regina and Minister for Agriculture, Fisheries and Food, ex Parte S.P. $\begin{array}{lllll}\text { Anastasiou (Pissouri) Ltd and others (2000). Retrieved from } & \end{array}$ 
http://curia.europa.eu/juris/showPdf.jsf?text=\&docid=101744\&pageIndex=0\&doclang=EN\&mode=req\&dir=\&occ $=$ first\&part $=1 \&$ cid $=934553$

Euroepan Court of Justice (2010). Case C-386/08 Firma Brita GmbH v Hauptzollamt Hamburg-Hafen of 25 February 2010. Retrieved from http://curia.europa.eu/juris/liste.jsf?language=en\&num=C-386/08

European Court of Justice (2016). C-104/16 P - Council v Front Polisario. Retrieved from http://curia.europa.eu/juris/liste.jsf?language $=$ en\&num $=\mathrm{C}-104 / 16$

European Court of Justice. (2019). C-363/18 Organization juive Europeenne, Vignoble Psagot LTD v. Ministre de l'Economie et des Finances. Retrieved from http://curia.europa.eu/juris/liste.jsf?num=C-363/1

European GSA (2020). Galileo is a European Global Satellite-Based Navigation System. Retrieved from https://www.gsa.europa.eu/european-gnss/galileo/galileo-european-global-satellite-based-navigation-system

European Parliament (2020). Parliamentary questions: Re-establishment of the EU-Israel Association Council under the new EU leadership. Retrieved from https://www.europarl.europa.eu/doceo/document/E-9-2020-000760_EN.html

European Union (1995). Barcelona Declaration Adopted at the Euro-Mediterranean Conference, 27-28/11/95. Retrieved from http://www.eeas.europa.eu/archives/docs/euromed/docs/bd_en.pdf

European Union (2011). Council Directive 2011/85/EU of 8 November 2011 on requirements for budgetary frameworks of the Member States. OJ L 306, 41.

European Union (2011a). Regulation (EU) No 1173/2011 of the European Parliament and of the Council of 16 November 2011 on the effective enforcement of budgetary surveillance in the euro area, OJ L 306, 1.

European Union (2011b). Regulation (EU) No 1175/2011 of the European Parliament and of the Council of 16 November 2011 amending Council Regulation (EC) No 1466/97 on the strengthening of the surveillance of budgetary positions and the surveillance and coordination of economic policies. OJ L 306, 12.

FEPS and Macro (2016). EU-Israel relations in Light of the new Middle East: insights from the conference "EU-Israeli relations and the changing dynamics of the Middle East", held in December 2016 in Tel Aviv.

FRA (2020). Antisemitism - Overview of Data Available in the EU 2008-2018. Retrieved from https://fra.europa.eu/en/publication/2019/antisemitism-overview-2008-2018

Globes (2016). Opening the Tap: Israel and Jordan Collaborate Regrading Water. [Hebrew]. Retrieved from https://www.globes.co.il/news/article.aspx?did=1001118061

Globes (2021). Israel and EU reach reciprocal Covid passport agreement. Retrieved from https://en.globes.co.il/en/articleisrael-and-eu-reach-covid-passport-agreement-1001384845

Gordon, N., and Pardo, S. (2014). Normative power Europe and the power of the local. Research Note, Journal of Common Market Studies. Retrieved from https://www.academia.edu/7366163/Neve_Gordon_and_Sharon_Pardo_2014_Normative_Power_Europe_and_the _Power_of_the_Local_Journal_of_Common_Market_Studies_5 3_2_pp._416-427._DOI_10.1111_jcms.12162

Gorodinski, Sonia (2021). FTA between Israel and the UAE? Walla 18.10.21 [Hebrew].

Gutman, L. (2014). Hapoalim Bank and the EIB will Finance the Establishment of a Powerhouse in Ashalim by 2.3 Million Shekels. Calcalist 26.6.14 [Hebrew].

Harari, M. (2021). Israel and the European Union: discoveries of energy and the new regional architecture in the Eastern Mediterranean - a strategic window of opportunity for expanding cooperation. IEPN, 7.10.21.

Harpaz, Y. (2013). Rooted Cosmopolitan: Israelis with a European Passport - History, Property, Identity. International Migration Review 47(1): 166-206.

Ilan, S. (2018). Israel's GDP per capita: Less then two thirds of US's GDP, 88\% of OECD average GDP. Calcalist 28.2.18 [Hebrew].

Israeli Ministry of Economy (2020). Free Trade Agreement Between the State of Israel and the Republic of Panama. https://www.gov.il/BlobFolder/policy/free-trade-area-agreement-israel-panama/he/sahar-hutz_agreements_panama- 
fta-en-2018.pdf

Israeli-Palestinian Interim Agreement on the West Bank and the Gaza Strip, concluded in Washington, D.C., September 28, 1995, ('Oslo Agreement'). https://www.mfa.gov.il/mfa/foreignpolicy/peace/guide/pages/the\%20israeli-

palestinian\%20interim\%20agreement.aspx

Israeli Central Bureau of Statistics (2019). www.cbs.gov.il.

Israeli Court of Justice (1981). ICJ 69/81 Abu Ita v. Commander of Judea and Samaria Region.

Israeli Court of Justice (1982). ICJ 393/82 Elmaamun V. the IDF Commander.

Israeli Ministry of Economy and Industry (2017). First Direct Financing of the EIB to the Israeli Bio-Pharma Company

Biondvax. $\quad$ Hebrew]. $\quad$ Retrieved from https:/israel-trade.net/int-
org/\%D7\%9E\%D7\%99\%D7\%9E\%D7\%95\%D7\%9F-\%D7\%99\%D7\%A9\%D7\%99\%D7\%A8-\%D7\%A8\%D7\%90 \%D7\%A9\%D7\%95\%D7\%9F-\%D7\%A9\%D7\%9C-\%D7\%94\%D7\%91\%D7\%A0\%D7\%A7-\%D7\%94\%D7\%90\% D7\%99\%D7\%A8\%D7\%95\%D7\%A4\%D7\%99-\%D7\%9C\%D7\%94\%D7\%A9\%D7\%A7\%D7\%A2/

ISERD (2019). Israel and Europe Research and Development Directorate. Retrieved from https://www.innovationisrael.org.il/ISERD/

Juncker, J. C. (2015). Completing Europe's Economic and Monetary Union. Retrieved from http://ec.europa.eu/priorities/economic-monetary-union/docs/5-presidents-report_en.pdf

Juncker, J. C. (2017). The White Paper on the Future of Europe: Reflections and Scenarios for the EU27 by 2025. March 1, 2017. Retrieved from https://ec.europa.eu/commission/sites/betapolitical/files/white_paper_on_the_future_of_europe_en.pdf

Kakabadse, M. A. (1987). International Trade in Services: Prospects for Liberalization in the 1990's, New York: Crom Helm.

Keidar, N. (2021). Israel will join Horizon Europe. Channel 7, 26.10.21 [Hebrew].

Levkowitz, A. (2017). Israel upgrades its Asia policy. BESA Center. https://besacenter.org/israel-asia-policy/

Marchetti, J. and Roy, M. (2008). Service Liberalization in the WTO and in PTAs, in: Marchetti J. and Roy, M. (eds.). Opening Markets for Trade in Services: Countries and Sectors in Bilateral Trade Negotiations. Cambridge: Cambridge University Press.

Melnick, R. (2003). Should Israel Join the EMU? IEPN Israeli European Policy Network, Friedich Ebert Stiftung, TelAviv.

Mitchell, G. (2020). The Eastern Mediterranean Gas Forum: Cooperation in the Shadow of Competition. Mitvim. Retrieved from https://mitvim.org.il/en/publication/the-eastern-mediterranean-gas-forum-cooperation-in-theshadow-of-competition/

MoEP - Ministry of Environmental Protection (2020). Twinning Project: 2015-2017. Retrieved from http://www.sviva.gov.il/English/env_topics/IndustryAndBusinessLicensing/EU-Twinning-

Program/Pages/Twinning-Project-2016-2018.aspx

Munin, N. (2003). Israel and the EU: State of the Play. Jerusalem: Israeli Ministry of Finance [Hebrew].

Munin, N. (2006). The New Israeli Civil Code and the Israel-EU action Plan on Free Trade Area in Services. IDC Journal on Law and Business 4: 465-498 [Hebrew].

Munin, N. (2008). The Union for the Mediterranean (UfM) Initiative and its Impact on Israel. In: Nathanson, R. and Stteter, S. (eds.) Renewing the Middle East: Climate Change in Security and Energy and the New Challenges for EU-Israel Relations, Tel Aviv: IEPN, pp. 233-239. Retrieved from https://www.iepn.org/images/stories/papers/renewingthemiddleeast.pdf

Munin, N. (2013). Women's Labor in Israel in Comparative Context: Politics and the Society versus Law, Justice and 
Economic Considerations? the International Journal of Euro-Mediterranean Studies (EMUNI), Vol. 5(2), 2013, pp. 93-107.

Munin, N. (2013). European Monetary Union's Single Banking Supervision Mechanism: Another Brick in the Wall? The IUP Journal of International Relations, Vol. X, No. 4, 2016, pp. 7-31.

Munin, N. (2020). International Trade in Corona Times: Current Dilemmas and Challenges, IUP Journal of International Relations, Vol. XIV, no. 3, pp. 48-63, 2020.

Munin, N. (2020a). Do The New Peace Agreements Between Israel and the Gulf States Set A 'Honey Trap' For Israel? Bratislava Law Review, Bratislava Law Review, 4(2), 95-110, 2020.Munin, N. and Sitbon, O. (2021). Between Normative Power and Soft Power: the Psagot Case, Australia New Zealand Journal of European Studies, Vol. 13(1), June 2021.

Munin, N. and Malka-Tiv, K. (2021). Tax Obedience in Corona Times. Journal of Multidisciplinary Research, St. Thomas University, Florida, Vol. 13(2), 5-19.

Nathanson, R. and Stteter, S. (eds.) (2006). Israeli European Policy Network: The Monitor of the EU-Israel Action Plan. Tel Aviv: IEPN. Retrieved from https://www.iepn.org/index.php?option=com_content\&view=article\&id=4\&Itemid=17

NoCamels (2020). 9 Israeli Organizations Win EU Innovative Program Grants to Tackle COVID-19. https://nocamels.com/2020/09/9-israeli-eu-innovation-covid-19-pandemic/

OECD (2020). Ensuring a strong, inclusive and sustainable recovery from the COVID-19 crisis in Israel. Retrieved from https://oecdecoscope.blog/2020/09/23/ensuring-a-strong-inclusive-and-sustainable-recovery-from-the-covid-19crisis-in-israel/

Pardo, S. (2013). The Year that Israel Considered Joining the European Economic Community. Journal of Common Market Studies 51 (5), pp. 901-915.

Pardo, S. and Peters, J. (2012, 2014 - reprinted). Israel and the European Union: A Documentary History, Lexington Books, Lanham MD

Pardo, S. and Zemer, L. (2019). The Status of EU Law as a Foreign Law in Israeli legislation - Anatomy of a System, Part 1 [Hebrew], Mishpat Ve'asakim Vol. 22, pp. 457-516. https://idclawreview.files.wordpress.com/2020/04/zemerpardo.pdf

Raz, M. (2019). Israeli Hotels in the First Quarter of 2019: More Tourist Person Nights than Local Person Nights. Globs, 16.4.19 [Hebrew].

Rotter (2019). The Minister of Economy Eli Cohen: The Trade Agreement Does not Include a Territorial Distinction and is Not Different from Other Agreements. 30.6.19 [Hebrew]. Retrieved from https://rotter.net/forum/scoops1/571321.shtml

Sher, G. (2018). The EU and the 'Two Nations' Solution: Is There a Chance for a Change? In: Rozner, Yotam and Kantor, Adi (eds.) The EU in Times of Upheavals: Trends, Challenges and Implications for Israel. Tel Aviv: INSS [Hebrew]. Retrieved from https://www.inss.org.il/he/wp-content/uploads/sites/2/2018/05/Memo175EU-1.pdf

Soler, E. (2021). The EU and Eastern Mediterranean: How to Deal with Turkey. Retrieved from https://www.cidob.org/en/publications/publication_series/notes_internacionals/251/the_eu_and_the_eastern_medit erranean_how_to_deal_with_turkey

Stein, R. (2015). Globes Presents: Financial Centralization in Insurance, Pensions and Banking. Globes, 7.5.15 [Hebrew]. Stone, M. and Patrick, J. (2013). The Educational Benefits of Travel Experience: A Literature Review. Journal of Travel Research 52(6): 731-744.

Stteter, S. (2008). The Barcelona Process: Union for the Mediterranean- Assessing its Impact for Euro-Mediterranean and EU-Israeli Relations. In: Nathanson, R. and Stteter, S. (eds.) Renewing the Middle East: Climate Change in Security 
and Energy and the New Challenges for EU-Israel Relations, Tel Aviv: IEPN, pp. 211-232. Retrieved from https://www.iepn.org/images/stories/papers/renewingthemiddleeast.pdf

Teleniri (2009). The EIB will Finance a Desalination Device in Ashdod. Teleniri 25.9.09 [Hebrew].

Terry, L. S. (2008). The Bologna Process and its Impact in Europe: It's so Much More than Degree Changes. 41 Vand. J.

Transnat'l L., p. 107-228. Retrieved from http://www.personal.psu.edu/faculty/1/s/lst3/Terry_vanderbilt_bologna.pdf

The Times of Israel (2021). Israel said asking US, EU: Apply our new rules on boosters to Israeli arrivals. Retrieved from

https://www.timesofisrael.com/israel-said-asking-us-eu-apply-our-new-rules-on-boosters-to-israeli-arrivals/

Tovias, A. (2003). Mapping Israel's Policy Options Regarding its Future Institutionalized Relations with the EU, CEPS.

Tovias, A. (2021). A quick survey of EU-Israel bilateral relations 25 years after the Barcelona process. EuroMesco Euromed survey.

Tovias, A. and Ugur, M. (2004). Can the EU Anchor Policy Reform in Third Countries? An Analysis of the Euro-Med Partnership, European Union Politics 5(4): 395-418.

Treaty on the European Union (TEU), consolidated version (2016). Retrieved from https://eur-lex.europa.eu/legalcontent/EN/TXT/?uri=CELEX:12016M/TXT

World Bank (2019). List of Sovereign States in Europe by GNI (PPP) per capita. Retrieved from https://en.wikipedia.org/wiki/List_of_sovereign_states_in_Europe_by_GNI_(PPP)_per_capita

World Bank (2021). GDP Per Capita (Current US\$) - Israel. Retrieved from https://data.worldbank.org/indicator/NY.GDP.PCAP.CD?locations=IL

WorldMeter (2020). Israel Population. Retrieved from https://www.worldometers.info/world-population/israelpopulation/.

Yehezkeli, Z. and Dery, D. (2012). Allah Islam - Documentary on the Muslims in Europe. 2012. Retrieved from https://www. youtube.com/watch?v=hR7REARFFpQ.

Zaken, Dany (2021). Israel and UAE Proceed Towards Concluding a FTA. Globes 17.10.21 [Hebrew]. Retrieved from ${ }^{x x}$ https://www.globes.co.il/news/article.aspx?did=1001387617

Zehavi, H. (2018). The Bologna Process in Israel as a Reflection of EU-Israel Relations. European Journal of Higher Education 9(1): 23-39.

Zeira, Y. (2018). Israel's Economy [Hebrew]. Tel Aviv: Yediot Sfarim.

\section{Copyrights}

Copyright for this article is retained by the author(s), with first publication rights granted to the journal.

This is an open-access article distributed under the terms and conditions of the Creative Commons Attribution license which permits unrestricted use, distribution, and reproduction in any medium, provided the original work is properly cited.

\footnotetext{
${ }^{\mathrm{i}}$ Values such as human dignity, freedom, equality, respect for human rights, including the rights of persons belonging to minorities, pluralism, non-discrimination, tolerance, justice, solidarity and equality between women and men. Like the EU, Israel aims at promoting peace, its values and the well-being of its citizens, striving to offer them freedom, security and justice are included in Arts. 2-3 of the Treaty on the European Union (TEU). Israel is not subject to the TEU and has no constitution. Nevertheless, these values are enshrined in a series of 'Basic Laws' Israel has enacted during the years, having a constitutional status, as well as in many Israeli High Court of Justice judgments.

ii Nevertheless, Cyprus became an EU member without being situated in 'Europe' and Turkey became an EU candidate although most of its territory is situated in Asia.

iii While this is the official EU position, its member states' position regarding it seem to be divided into three blocks (Assenburg, 2019, 66).
} 
iv More details are retrieved from: https://ufmsecretariat.org/who-we-are/. For impact analysis on this program on Israel see: Stteter, 2008; Munin, 2008; Tovias, 2021.

$\checkmark$ Retrieved from https://library.euneighbours.eu/content/eu-israel-enp-action-plan

${ }^{\text {vi }}$ Before Cyprus joined the EU in 2004, the latter tried to impose a political arrangement that would solve the old GreekTurkish conflict over North Cyprus. It was rejected in a referendum by the Greek-Cypriot population and nevertheless Cyprus became an EU member state.

vii This scheme entitles goods originating in two or more of the eligible states to trade benefits, when exported to the EU. See more details in European Commission, 2019.

viii As long as Israel is not an EU member, even if it adopts such EU arrangements unilaterally and voluntarily, the different legal context may imply their different development in terms of future amendments and interpretation, in comparison to EU legislation and interpretation.

ix The EU extended Brita interpretation to apply to agriculture, research and development, education, sports and other activities taking place in the territories. (European Commission 2011, 2013, 2013a, 2014, 2015). Psagot case extended it further, to consumer protection labelling. Other Israeli free trade area agreements, such as the agreement with the US and the recently concluded agreement with South Korea also exclude the territories from their scope of application (Rotter, 2019), but these agreements are seldom publicly discussed.

${ }^{x}$ This pragmatic approach corresponds to that adopted by the EU itself in other areas under contested sovereignty, e.g. North Cyprus (CJEU, 2000); the case of Ceuta and Melilla (under political dispute between Spain and Morocco), as well as to the WTO notion of 'customs territories', embodied in GATT Arts. XXIV and XXVI.

xi The CJEU judgment in the case of Front Polisario (CJEU, 2016) follows a similar logic.

xii Other grounds for EU avoidance to conclude such an agreement with Israel include EU priorities. In recent years, the global TISA (Trade in Services Agreement) initiative - a complementary agreement to the 1995 GATS that could have rendered a bilateral agreement unnecessary - formed another reason for delay. This initiative was undermined by the US's Trump administration.

xiii GNI of EU members is the major resource for EU budget, comprising about $56 \%$ of it, complementing traditional own resources, VAT-based contributions and other revenues. (European Commission, 2017).

xiv Being WTO members, the two parties enjoy the free movement of persons benefits provided for by the General Agreement on Trade in Services (GATS), reinforced by Arts. 29-30 of the Association Agreement between them, but these benefits are quite limited due to the multilateral framework in which they were given. Bilaterally, better terms may be obtained through mutual agreement. (Marchetti and Roy, 2008, 82).

${ }^{x v}$ In EU context, free movement of persons is subject to security exceptions which would have applied to Israel, had it become a member state. Nevertheless, the effectiveness of these exceptions is constantly challenged in EU reality: see, e.g. Yehezkeli and Dery, 2012.

xvi In the first quarter of 2019, tourist person-nights amounted to 54\% of total person-nights in Israeli hotels. (Raz, 2019).

xvii Based on Arts. 29 (services liberalization), 57 (immigration policy), 64 (coordination of social security regimes) of the Association Agreement.

xviii Sharing the limited regional water resources forms a decisive aspect of Israel-Jordan's peace agreement of 1994. In 2010 a complementary agreement between the parties was concluded, providing for mutual exchange of fresh water for desalinated water. Desalination enlarges the overall quantity of sweet water in this region, which including substantial areas of desert suffers constantly from water shortage. (Globes, 2016).

xix A well known example to such a successful business is Grandma Jamila's soap factory. (Embassy of Israel, Madrid, 2016). 